\title{
HUBUNGAN PARITAS DENGAN KEJADIAN HIPEREMESIS GRAVIDARUM PADA IBU HAMIL
}

\author{
Kristina Paskana ${ }^{1}$, Vevi Gusnidarsih ${ }^{2}$ \\ ${ }^{1,2)}$ Akademi Kebidanan Manna \\ kristinapaskana04@gmail.com
}

\begin{abstract}
ABSTRAK
Di Indonesia ibu hamil yang mengalami hiperemisis gravidarum sebanyak 50-90\% sering dijumpai pada kehamilan trimester pertama. Berdasarkan survei awal dari data register Rumah Sakit Hassanuddin Damrah Manna Bengkulu Selatan tahun 2019 kejadian hiperemesis gravidarum tercatat 78 orang dari 200 orang ibu hamil. Tujuan penelitian ini untuk mengetahui hubungan paritas dengan kejadian hiperemesis gravidarum pada ibu hamil di Rumah Sakit Hassanuddin Damrah. Penelitian ini dilakukan di Rumah Sakit Hassanuddin Damrah Manna Bengkulu Selatan. Penelitian ini merupakan penelitian deskriptif korelasional dengan pendekatan cross sectional. Populasi dalam penelitian ini adalah seluruh ibu hamil usia $\leq 20$ minggu yang dirawat di Rumah Sakit Hassanuddin Damrah Manna tahun 2019 yang berjumlah 200 orang. Teknik pengambilan sampel menggunakan total sampling. Pengumpulan data dalam penelitian ini menggunakan data sekunder yang di peroleh dari catatan medik Rumah Sakit Hassanuddin Damrah Manna, kemudian data diolah secara univariat dan bivariat. Hasil penelitian didapatkan nilai $p=0,000<0,05$, yang artinya terdapat hubungan antara paritas ibu dengan kejadian hiperemesis gravidarum di Rumah Sakit Hassanuddin Damrah Manna Bengkulu Selatan.
\end{abstract}

Kata kunci : hiperemesis gravidarum, paritas, primigravida

\section{Abstract}

In Indonesia, pregnant women who have hyperemesis Gravidarum as much as 50-90\%, which is often found in the first-trimester pregnancy. Based on the initial survey from the data register of hospital Hassanuddin Damrah Manna in South 2019, the incidence of hyperemesis gravidarum recorded in 78 out of 200 pregnant women. The purpose of this research is to know the parity relationship with the Incidence of Hyperemesis Gravidarum in Pregnant Women at Hassanuddin Damrah Hospital. The research conducted at Hassanuddin Damrah Manna Hospital. This research a correlational descriptive study with a cross-sectional approach. The population in this study is all pregnant mothers aged $\leq 20$ weeks hospitalized at Hassanuddin Damrah Manna Hospital in 2019, which amounted to 200 people. Sampling techniques using total sampling. Data collection In this study uses secondary data obtained from the medical record of Hassanuddin Damrah Manna Hospital. Then the data is processed univariate and Bivariate. Research results in a value $P=0.000<0.05$, which means there is a link between the parity of the mother with the incidence of hyperemesis gravidarum in the Hassanuddin Damrah Manna South Bengkulu Hospital.

Keywords: gravidarum hyperemesis, parity, primigravida 


\section{PENDAHULUAN}

Kehamilan adalah salah satu tahapan dari kehidupan wanita yang terjadi secara alamiah. Ibu hamil memerlukan perawatan yang khusus supaya proses kehamilannya berjalan lancar serta menghindari beberapa komplikasi yang sering terjadi selama hamil. Salah satu komplikasi yang sering terjadi pada wanita hamil adalah kejadian mual dan muntah. Jika mual dan muntah ini terjadi secara berlebihan lebih dari 10 kali dalam 24 jam serta dapat mengganggu proses aktivitas dan membahayakan ibu dan janin disebut dengan hiperemisis gravidarum (Primigravida, 2016).

Ibu hamil biasanya dapat dikatakan mengalami hiperemesis gravidarum jika mengalami muntah beberapa kali dalam sehari, atau selalu muntah setiap kali makan atau minum, atau jika berat badan turun. Biasanya kondisi ini terjadi pada sekitar minggu ke empat dan ke tujuh, dan berangsur membaik pada minggu ke14 dan 16 kehamilan (Atalya, 2018). Sementara menurut Amiruddin (2012) dalam artikel Ummi Aiman, mual muntah secara berlebihan yang terjadi lebih dari 10 kali selama 24 jam disebut hiperemesis gravidarum. Pada kasus HEG cadangan karbohidrat dan lemak habis untuk energi. Hal tersebut dapat menyebabkan dehidrasi pada ibu hamil yang akan mempengaruhi tumbuh kembang janin (Ummi aiman, 2019).

Hiperemesis gravidarum yang terjadi akan sangat mempengaruhi aktifitas ibu hamil sehari-hari. Selain dapat mengganggu aktivitas, hiperemesis dapat mengakibatkan penurunan berat badan ibu sebanyak 50\% serta dapat menyebabkan terganggunya fungsi alat-alat vital di dalam tubuh yang dapat berakibat kematian (Manuaba, 2014)

Hiperemesis gravidarum merupakan salah satu komplikasi pada ibu hamil trimester pertama kejadian ibu hamil yang mengalami hiperemisis gravidarum sebanyak $40-60 \%$ terjadi pada ibu hamil multigravida dan sekitar 60$80 \%$ terjadi pada ibu hamil primigravida, yang mengalami mual muntah ini dapat menjadi lebih berat pada 1 dari 1000 kehamilan (Hackley dan Barbara, 2012).

Faktor yang dapat menyebabkan hiperemisis gravidarum ini secara pasti belum diketahui. Ada beberapa faktor yang diduga dapat menyebabkan hiperemisis gravidarum pad ibu hamil yaitu ibu hamil anak pertama (primigravida), hamil dengan riwayat molahidatidosa serta hamil kembar/ganda (Kemenkes RI 2019, n.d.).

Berdasarkan hasil penelitian Indrayani Triana (2018), bahwa ibu dengan primigravida lebih tinggi beresiko terjadinya hiperemesis gravidarum daripada ibu hamil dengan multi gravida. Hal ini dikarenakan pada ibu hamil primigravida secara fisik belum ada kesiapan untuk menerima pertumbuhan serta perkembangan janin yang ada di dalam rahimnya. Selain itu pada ibu hamil primigravida yang juga belum mampu beradaptasi dengan perubahan yang dialaminya selama kehamilan mulai dari perubahan organ tubuh, perubahan hormone, dan perubahan lainnya (Indrayani, 2018).

Berdasarkan survei awal dari data register rawat inap Kebidanan di Rumah Sakit Hasanuddin Damrah Manna Bengkulu Selatan kejadian hiperemesis gravidarum terus mengalami peningkatan. Pada tahun 2017 ibu hamil yang mengalami hiperemesis gravidarum berjumlah 45 orang, pada tahun 2018 berjumlah 58 orang, dan pada tahun 2019 meningkat menjadi 78 orang (Rekam Medik Rsud HD, 2019).

Semakin meningkatnya angka kejadian hiperemesis gravidarum di Rumah Sakit Hassanuddin Damrah Manna, maka peneliti tertarik untuk mengatahui apakah ada antara paritas dengan kejadian hiperemesis gravidarum pada ibu hamil di Rumah Sakit Hasanuddin Damrah Manna Bengkulu Selatan. 


\section{METODOLOGI}

Penelitian ini telah dilaksanakan pada tanggal 08 Juni 2020 sampai dengan 13 Juni 2020 di Rumah Sakit Hasanuddin Damrah Manna Bengkulu Selatan. Metode penelitian yang digunakan pada penelitian ini adalah deskriptif korelasional dengan pendekatan cross sectional (Nurssalam, 2013). Populasi pada penelitian ini adalah seluruh ibu hamil usia $\leq 20$ minggu yang dirawat di Rumah Sakit Hasanuddin Damrah Manna tahun 2019 yang berjumlah 200 orang. Tehnik pengambilan sampel dilakukan dengan total sampling yaitu keseluruhan jumlah populasi ibu hamil usia $\leq 20$ minggu yang dirawat di Rumah Sakit Hasanuddin Damrah Manna tahun 2019. Teknik Pengumpulan data dalam penelitian ini menggunakan data sekunder yang diperoleh dari catatan medik Rumah Sakit Hasanuddin Damrah Manna. Dalam pengumpulan data ini peneliti dibantu petugas bagian medical record. Analisis data dilakukan secara univariat dan bivariat.

\section{HASIL}

\section{Analisis Univariat}

a. Angka kejadian hiperemesis gravidarum di RS Hasanuddin Damrah
Tabel 1. Distribusi Frekuensi Hiperemesis Gravidarum di RS Hasanuddin Damrah

\begin{tabular}{lcc}
\hline $\begin{array}{c}\text { Hiperemesis } \\
\text { Gravidarum }\end{array}$ & n & \% \\
\hline HEG & 78 & 39 \\
Tidak HEG & 122 & 61 \\
\hline Jumlah & $\mathbf{2 0 0}$ & $\mathbf{1 0 0}$ \\
\hline
\end{tabular}

Dari tabel diatas dapat diketahui bahwa sebagian ibu yang mengalami hiperemesis gravidarum lebih sedikit yaitu 78 orang.

b. Paritas Ibu di RS Hasanuddin Damrah

Tabel 2. Distribusi Frekuensi Paritas Ibu di RS Hasanuddin Damrah Manna

\begin{tabular}{lcc}
\hline \multicolumn{1}{c}{ Paritas } & n & \% \\
\hline Multigravida & 94 & 47 \\
Primigravida & 106 & 53 \\
\hline Jumlah & $\mathbf{2 0 0}$ & $\mathbf{1 0 0}$ \\
\hline
\end{tabular}

Dari tabel 2 di atas dapat diketahui bahwa sebagian besar ibu dengan paritas primigravida.

\section{Analisis Bivariat}

Hubungan Paritas Ibu dengan hiperemesis gravidarum di Rumah Sakit Hasanuddin Damrah.

Tabel 3. Hubungan Paritas Ibu dengan Hiperemesis Gravidarum di RS Hasanuddin Damrah Manna

\begin{tabular}{|c|c|c|c|c|c|c|c|c|}
\hline \multirow{3}{*}{ Paritas Ibu } & \multicolumn{4}{|c|}{ Hiperemesis Gravidarum } & \multirow{2}{*}{\multicolumn{2}{|c|}{ Total }} & \multirow{3}{*}{$\mathbf{x}^{2}$} & \multirow{3}{*}{$p$} \\
\hline & \multicolumn{2}{|c|}{ Ya } & \multicolumn{2}{|c|}{ Tidak } & & & & \\
\hline & n & $\%$ & n & $\%$ & $\mathbf{n}$ & $\%$ & & \\
\hline Multigravida & 15 & 15,9 & 79 & 84,1 & 94 & 100 & \multirow{2}{*}{37,777} & \multirow{2}{*}{0,000} \\
\hline Primigravida & 63 & 59,4 & 43 & 40,6 & 106 & 100 & & \\
\hline Total & 78 & 75,3 & 122 & 124,7 & 200 & 100 & & \\
\hline
\end{tabular}

Dari 106 orang ibu hamil primigavida terdapat 63 orang $(59,4 \%)$ ibu yang mengalami hiperemesis dan 43 orang $(40,6 \%)$ tidak mengalami hiperemesis. Hasil uji chi-square didapatkan nilai $\mathrm{x}^{2}=37,7$ dengan nilai $\mathrm{p}=$ $0,000<0,05$, artinya terdapat hubungan antara paritas ibu dengan kejadian hiperemesis gravidarum di RS Hasanuddin Damrah. 


\section{PEMBAHASAN}

Berdasarkan tabel 3 hasil analisis hubungan antara paritas dengan kejadian hiperemesis gravidarum dapat dilihat bahwa ibu primigravida yang mengalami hiperemesis gravidarum mempunyai presentasi lebih besar dari ibu multigravida yaitu 59,4\%. Hasil uji statistic diperoleh nilai $\mathrm{p}=0,000<0,05$, maka keputusannya yaitu Ha diterima dan disimpulkan ada hubungan antara paritas dengan kejadian hiperemesis gravidarum di Rumah Sakit Hasanuddin Damrah.

Hal ini disebabkan karena pada ibu hamil primigravida belum memiliki kesiapan baik secara fisik (menerima pertumbuhan dan perkembangan janin di dalam rahim) maupun psikologis dalam menghadapi perubahan selama kehamilan oleh sebab itu hiperemesis sering terjadi pada ibu hamil primigravida (Muchtar, 2018).

Hasil penelitian ini sejalan dengan penelitian Lina Oktavia (2016), yang menyatakan ibu hamil primigravida sering mengalami hiperemesis gravidarum hal ini disebabkan ibu belum mampu beradaptasi dan menyesuaikan dengan peningkatan kadar hormon estrogen dan HCG yang dapat memberikan efek mual dan muntah pada ibu (Oktavia, 2016).

Pada penelitian Handayani, bahwa hiperemesis gravidarum sebagian besar terjadi pada ibu dengan paritas resiko tinggi yaitu pada ibu hamil paritas 1 atau primigravida dan ibu dengan paritas lebih dari 3, karena pada paritas resiko tinggi sering terjadi kerusakan pada pembuluh darah dinding uterus akibatnya fungsi lambung menjadi tidak stabil yang berefek ada asam lambung meningkat yang menjadi penyebab mual dan muntah pada ibu (Handayani \& Aiman, 2018).

Menurut Wiknjaksastro kejadian HEG $60-80 \%$ terjadi pada ibu primigravida dan 40 $60 \%$ terjadi pada ibu multigravida. Peningkatan hormone estrogen dan HCG akibat system saraf menyebabkan mual dan muntah pada ibu hamil. Keluhan mual dan muntah biasanya terjadi pada pagi hari saat perut kososng dan terjai peningkatan asam lambung (Wiknjaksastro Hanifa, 2012).

\section{SIMPULAN DAN SARAN}

\section{Simpulan}

1. Dari 200 orang ibu hamil di RS Hassanuddin Damrah Manna terdapat 78 (39\%) yang mengalami hiperemesis gravidarum.

2. Dari 200 orang ibu hamil di RS Hassanuddin Damrah Manna terdapat 106 (53\%) ibu hamil dengan paritas primigravida.

3. Ada hubungan antara paritas ibu dengan kejadian hiperemesis pada ibu hamil di RS Hassanuddin Damrah.

\section{Saran}

1. Bagi RS Hassanuddin Damrah Manna

Hasil penelitian ini diharapkan bagi petugas kesehatan di Rumah Sakit mampu memberikan informasi kepada ibu hamil mengenai hiperemesis gravidarum sehingga ibu hamil dapat mengatasi mual muntah pada saat hamil.

2. Bagi Peneliti Lain

Hasil penelitian diharapkan dapat menjadi referensi dan informasi bagi peneliti lain untuk dapat mengembangkan ruang lingkup penelitian lebih lanjut dengan penambahan variabel lainnya yaitu pendidikan, pengetahuan, dan psikologi mengenai hiperemesis gravidarum.

\section{DAFTAR PUSTAKA}

Atalya. (2018). Hiperemesis gravidarum, mual muntah kronis saat hamil. In ibupedia.id.

Hackley dan Barbara. (2012). Primary care of women a quade for midwives providers 1 . Jones dan barlett learning. 
Handayani, S., \& Aiman, U. (2018). Analisis kejadian hiperemesis gravidarum (HEG) berdasarkan karakteristiknya. Babul Ilmi Jurnal Ilmiah Multi Science Kesehatan, 9(1), 99-108. http://www.jurnal.stikesaisyiyah-palembang.ac.id/index.php/ Kep/article/view/123/104

Indrayani, T. (2018). Faktor-faktor yang berhubungandengankejadianhiperemesis gravidarum Di Rsud Dr. Drajat Prawiranegara Kabupaten Serang Tahun 2017. Jurnal Akademi Keperawatan Husada Karya Jaya, 4(1), 9-21. http:// ejurnal.husadakaryajaya.ac.id/index.php/ JAKHKJ/article/view/70/63\%0Ahttp:// ejurnal.husadakaryajaya.ac.id/index.php/ JAKHKJ/article/view/70

Kemenkes RI 2019. (n.d.). Profil kesehatan indonesia 2018. Kementerian Kesehatan Republik Indonesia.

Manuaba. (2014). Ilmu kebidanan, penyakit kandungan dan keluarga berencana untuk pendidik bidan (EGC).

Muchtar, A. S. (2018). Hubungan umur dan paritas ibu hamil dengan kejadian hiperemesis gravidarum. Jurnal Ilmiah Kesehatan Diagnosis, 12(6), 598-602.

Nurssalam. (2013). Metodologi penelitian (Salemba Me).

Oktavia, L. (2016). Kejadian hiperemisis gravidarum ditinjau dari jarak kehamilan dan paritas. Jurnal Aisyah : Jurnal Ilmu Kesehatan, 1(2), 41-46. https://doi. org/10.30604/jika.v1i2.19

Primigravida, G.P.(2016). Hubungan tingkat stres dengan kejadian hiperemesis gravidarum pada primigravida. Mitra3 Program Studi Ilmu Keperawatan Fakultas Kedokteran Universitas Sriwijaya, 1-10.

Rekam Medik Rsud HD. (2019). Pelaporan hasil rekam medik rsud hassanudin damrah manna.

Ummi aiman. (2019). Hubungan paritas dengan kejadian hiperemesis gravidarum di rsud salatiga. Universitas Ngudi Waluyo, 8(5), 55.

Wiknjaksastro Hanifa. (2012). Ilmu kebidanan. Yayasan Bina Pustaka Sarwono. 
